\title{
ANTIBODY PROFILE IN LAYING BIRDS VACCINATED WITH NEWCASTLE DISEASE VACCINE, LA SOTA
}

\author{
OKWOR $^{1}$ E.C.; EZE $^{1 *}$ D.C., NGWU ${ }^{1}$ M.I., ONONIWU ${ }^{1}$ C.N., AND \\ ECHEONWU ${ }^{2}$ G.O.
}

${ }^{\mathbf{1}}$ Department of Veterinary Pathology and Microbiology, University of Nigeria, Nsukka.

${ }^{2}$ National Veterinary Research Institute, Vom, Plateau State, Nigeria.

*E mail: eldidacuscj@yahoo.com Phone: +2348037292020

\section{SUMMARY}

Newcastle disease (ND) is endemic in Nigeria and constitutes a major problem to poultry production especially commercial egg production. Despite vaccination of birds, some farmers and other stakeholders still believe that there is shortened protection interval between vaccinations leading to frequent outbreaks. This work studied the antibody profile in vaccinated birds using Newcastle disease vaccine, La Sota (NDVL) with a view to establishing the rise and decline in antibody titre after vaccination and thereby determining the protection interval in our local environment. Two hundred and eighty (280) Shaver brown layers at $\mathbf{7 8 \%}$ hen house production were used for the experiment. When their antibody levels were at Geometric Mean Titre of 12.1, they were vaccinated with NDVL through the oral route. On a monthly basis, the antibody titre was determined and 80 birds were taken to a distant location and challenged with a velogenic strain of Newcastle disease virus (NDV). Results showed good protection at 4 weeks, fair protection at 8 weeks and no protection at 12 weeks post vaccination $(\mathrm{PV})$. We therefore recommend that under the Nigerian condition, laying flocks should be revaccinated at 7-8 weeks interval with NDVL.

KEYWORDS: Antibody, Newcastle disease, Vaccination, Immunity, LaSota

Introduction

Newcastle disease (ND) is an acute, contagious viral disease of domestic poultry and many other species of birds causing high morbidity and mortality (Aini et al., 1990). It is world wide in distribution and the velogenic strain can cause mortalities ranging from $80-100 \%$ in unvaccinated birds (Alexander, 1997). The disease presents primarily as a respiratory disease with depression, nervous manifestations and diarrhea. The disease is caused by a filterable virus known as Newcastle disease virus (NDV) which is an RNA virus belonging to the genus Rubulavirus and
Family Paramyxoviridae enveloped with helical symmetry and negative sense single stranded genome (Seal et al., 2000).

ND is endemic in Nigeria and has been a limiting factor to poultry meat and egg production (Saidu et al., 1994). Poultry production in Nigeria combines the exotic types which are mostly reared on commercial basis and the local chickens which are mostly scavengers. For the farmers who produce eggs, common experience has shown inconsistent production among the layers. Vaccinations against ND do not produce protection lasting 
for a reasonable period. There have been reports of frequent outbreaks of sub clinical ND in vaccinated birds resulting in reduced egg production and accompanying economic losses. Sometimes, the condition will not show any overt sign but what is noticed is reduced egg production, and production of eggs with aberrant and discoloured shells. Because of this, many farmers and professionals have resorted to their own self designed schedule of vaccination with varying results. This work therefore investigated the antibody profile in laying birds with the aim of establishing the decline and possibly recommends intervals between revaccinations.

\section{MATERIALS AND METHODS}

Chicken: A total of 280 shaver brown layers were used for the experiment. The birds were 48 weeks old and at an average of $78 \%$ hen house-egg production. They were kept under deep litter system with feed and water given ad-libitum. The birds were vaccinated against ND, Infectious bursal disease and Fowl pox during the brooding stages.

Vaccine: Newcastle disease vaccine, La Sota (NDVL) was procured from the National Veterinary Research Institute (NVRI) Vom Plateau State. Before administration to the birds, the strength of the vaccine was tested using Haemagglutination (HA) test by the method described by Allan, and Gough (1974).

Vaccine administration: The antibody levels in the birds were monitored until it was at HI titre of $\leq 2$ (Beard, 1989). A vial of the vaccine containing 200 doses was reconstituted with $200 \mathrm{ml}$ of distilled water. Each bird was vaccinated with a single dose $(1 \mathrm{ml})$ of the vaccine through the oral route by drenching.
Antibody determination: The antibody responses in the birds were determined at 4, 8 and 12 weeks post vaccination (PV) using $\mathrm{H} 1$ test.

Virus Challenge: At 4, 8 and 12 weeks PV, 80 birds were challenged with a velogenic (VGF-1) NDV strain by the intramuscular route (Echeonwu et al., 1993). An ampoule containing this virus in a freeze-dried state was reconstituted with $2 \mathrm{ml}$ of distilled water. This suspension was further diluted with phosphate buffered saline (PBS) at a ratio of $1: 1000$ to give a median embryo infective dose $\left(\mathrm{EID}_{50}\right)$ titre of $10^{6.36}$ per $\mathrm{ml}$. Each bird was challenged with $0.2 \mathrm{ml}$ of this inoculum. The following parameters were monitored 3 days post challenge (PC)development of clinical signs; percentage egg production; mortalities; and virus isolation from cloacal swabs.

\section{Haemagglutination (HA) and Heamagglutination Inhibition (HI) Tests}

Two milliliters $(2 \mathrm{ml})$ each of ND antibody free blood was collected from three adult birds in a test tube containing EDTA as anticoagulant. The blood was washed in phosphate buffered saline (PBS) by centrifugation at $3000 \mathrm{rpm}$ for 5 minutes. This was repeated until a clear supernant was obtained. The packed RBC was resuspended in a measured volume of PBS solution to make 0.5 per cent RBC suspension (Beard, 1989).

\section{Haemagglutination (HA) Test:}

The HA titre of the antigen was determined as described by Allan, and Gough (1974) and Allan et al., (1978) and diluted to contain 4-HA units. This concentration was used for the HI test. 
Heamagglutination Inhibition (HI) Test:

The HI titers of the sera were expressed as reciprocal of the last dilution showing no agglutination of the RBC (Beard, 1989). The GMT was calculated using the Tube number method and Table described by Villegas and Purchase (1989).

\section{Virus Isolation}

Virus isolation was done according to procedures outlined by Kalter, (1963). The virus was re-isolated in 9-10 day-old embryonated specific antibody negative (SAN) chicken eggs by inoculation with 0.1 $\mathrm{ml}$ infectious cloacal samples into the allantoic cavity OIE, (2005).

\section{RESULTS}

\section{Antibody Profile}

Antibody profile as determined by $\mathrm{HI}$ test was very low before vaccination with NDVL, high at 4 weeks PV, declined at 8 weeks PV and became low at 12 weeks PV (Table I).
Clinical signs: No clinical sign was observed in the birds challenged at 4 weeks PV. Those challenged at 8 weeks PV showed slight reduction in feed and water consumption, slight dullness and mild diarrhea. Those challenged at 12 weeks showed signs of ND with marked reduction in feed and water consumption, greenish diarrhea and loss of body condition(Table II).

Average egg production: However, egg production dropped from $78 \%$ before vaccination to $59 \%$ at 4 weeks PV ; $43 \%$ at 8 weeks PV; and $14 \%$ at 12 weeks PV.

Mortality: No mortality occurred at 4 weeks PV; one bird died at 8 weeks PV while a total of 21 birds died at 12 weeks PV.

Virus isolation: Ten birds each were used for this and virus was isolated from the cloacal swab of 1 bird at 4 weeks PV, 5 birds at 8 weeks PV and from all the birds examined at 12 weeks PV.

Table I: Antibody profile in laying birds as determined by Geometric Mean Titre (GMT) before and after vaccination with NDVL.

\begin{tabular}{lllll}
\hline & Before Vaccination & 4 weeks PV & 8 weeks PV & 12 weeks PV \\
\hline GMT & 12.1 & 299.0 & 84.4 & 37.0 \\
\hline
\end{tabular}


Table II: Summary of Values obtained with the Parameters Examined

\begin{tabular}{|c|c|c|c|c|}
\hline Parameter & Before Challenge & $\begin{array}{l}\text { Challenged } 4 \\
\text { weeks Post } \\
\text { Vaccination }\end{array}$ & $\begin{array}{l}\text { Challenged } 8 \\
\text { weeks Post } \\
\text { Vaccination }\end{array}$ & $\begin{array}{l}\text { Challenged } 12 \\
\text { weeks Post } \\
\text { Vaccination }\end{array}$ \\
\hline Clinical signs & Nil & Nil & + & ++ \\
\hline $\begin{array}{l}\text { Average egg } \\
\text { Production in } \%\end{array}$ & $78 \%$ & $59 \%$ & $43 \%$ & $14 \%$ \\
\hline Mortality (\%) & Nil & Nil & $1 / 80(1.25 \%)$ & $21 / 80(26.25 \%)$ \\
\hline $\begin{array}{l}\text { Virus Isolation } \\
(\%)\end{array}$ & Nil & $10 \%$ & $50 \%$ & $100 \%$ \\
\hline
\end{tabular}

\section{Discussion}

Vaccination in broiler chicks can be especially difficult due to the presence of maternal antibodies and because of their short life such that broiler chickens are not vaccinated in countries where there is low risk of ND (Alexander 1997). This cannot be possible in Nigeria because of the endemicity of ND. Vaccination of laying birds has always required more than one vaccination to maintain immunity throughout their lives, and this actually depends on the local condition (Allan et al, 1978). Local custom or circumstances result in too little vaccination, over vaccination or mistiming of vaccination, all of which may have serious consequences. The problem affects poultry farmer in tropical developing countries and frequently results in what has been described as "vaccine abuse" (Higgins and Shortridge, 1988).

The result showed that there was good protection at 4 weeks $\mathrm{PV}$, fair protection at 8 weeks PV and no protection at 12 weeks PV.

Virus isolation from some birds challenged before 12 weeks PV agrees with the observation of Parede and Young (1990) that ND vaccination protects birds from more serious consequences of disease; but virus replication and shedding may still occur although at a reduced level. Moreover, Ezema et al., (2008), observed histopathological lesions in chickens 3 weeks after vaccination without overt clinical disease, therefore, vaccination against ND can protect birds from clinical disease but not from development of some 
histopathological lesions and slight multiplication of the virus. The development of antibody after vaccination of layers declines appreciably within a short time in ND and this depends on certain conditions one of which is the transfer of the immunoglobulin in the eggs laid by the birds. Estimation of this decline rate within a region will be helpful in determining periods between revaccinations (Spradbrow, 1999). Alexander (1999) listed the different parameters that must be considered in devising vaccination programme as disease situation, disease control policies, presence of other organisms, size of flock, expected life of the flock, available labour, climatic condition, economics of vaccination, type of vaccine and past performance of vaccination programmes. In Nigeria, ND is endemic with the environment being heavily contaminated with other infectious agents. Therefore frequent vaccination against ND is more indicated in laying flock than in non laying flock.

From this work, we recommend that laying birds should be vaccinated with NDVL at 78 weeks interval for maximum protection against ND.

\section{REFERENCES}

AINI, I., IBRAHIM, A., and SPRADBROW, P. B. (1990). Field trails of food based vaccine to protect village chickens against Newcastle disease. Research in veterinary science 49: 216-219.

ALEXANDER, D.J. (1997). Newcastle disease and other Avian Paramyxovirus infections. In B.W. Calrek, H.J. Barnes, C.W. Beard, L.R. Dougald and Y.M. Saif (eds) Diseases of Poultry $10^{\text {th }}$ ed pp 541570.
ALEXANDER, D.J. (1999). Paramyxoviridae In: Jordan F.T.W. and Pattison $M$ (eds) poultry diseases. N.B. Saunders, London. Pp 139-155.

ALLAN, W. H, GOUGH, R. E (1974). Standard Haemaglutination Inhibition test for Newcastle disease. 2. Vaccination and Challenge. Vet. Res. 95: 147-149.

ALLAN, W.H., LANCASTER, T.E., and TOTH, B. (1978). Newcastle disease vaccines - their production and uses, FAO Animal Production service No 10 FAO Rome.

BEARD, C. W. (1989). Serologic Procedures. In A Laboratory Manual for the Isolation and Identification of Avian Pathogens. 3rd. H. G. Purchase, L H. Arp, C. H. Domermuth, and J. E. Pearson (eds.), Kennett Square, PA: Amer. Assoc. Avian Pathologist,.pp 192-200.

ECHEONWU, G.O. IROEGBU, C.U., and EMERUWA, A.C. (1993). Recovery of velogenic Newcastle disease virus from dead and healthy free roaming birds in Nigeria. Avian Pathology 22: $283-284$.

EZEMA, W. S., OKOYE, J. O. A and NWANTA, J. A. (2008). La Sota Vaccination may not protect against the lesions of velogenic Newcastle disease in chickens. Tropical Animal Health and Production (In Press).

HIGINS, D.A. and SHORTRIDGE, K.F. (1988). Newcastle disease in tropical and developing countries. In D.J. Alexander (ed) Newcastle disease. 
Klumer Academic Publishers. Boston M.A. pp 273-302.

KALTER, S. S. (1963). Procedures for the Routine Laboratory Isolation of viruses and Rickettsail diseases. Burgess Publishing co. Minneapolis, pp19-28.

OIE., 2005 (Office International des Epizooties/World Organization for Animal Health). Newcastle disease. In: Manual of standards for diagnostic tests and vaccines. Chap 2.1.15.

PAREDE, L., and YOUNG, P.L. (1990). The pathogenesis of Velogenic Newcastle disease infection of chickens of different ages and different levels of immunity. Avian Diseases 34: 803-808.

SAIDU, L., NWANGU, B. I. AND

OTCHERE, E. O., (1994). Disease of Nigerian indigenous chicken. Bulletin of Animal Health and Production in Africa, 42, 17-28.

SEAL, B.S., KING, D.J., and MEINERSMANN， R.J. (2000). Molecular Evolution of the Newcastle disease virus matrix protein gene and phylogenic relationship among the paramyxoviridae. Virus Research, 66: $1-11$.

SPRADBROW, P. B. (1999). Epidemiology of Newcastle disease and the Economic of its control. Proceedings of the workshop on poverty eradication and promotion of gender equality. March, 2006, pp $165-173$.

VILLEGAS, P. and PURCHASE, H.G. (1989). Titration of biological suspension. In A laboratory manual for the isolation and identification of avian pathogens. Iowa. USA. Kendal
Hunt. America Association of Avian Pathologists: 186-190. 